\title{
Non-Financial Disclosure Assurance: Critical Insights from the Italian Financial Services Sector
}

\author{
Alessandra Pagani ${ }^{1}$, Sara Moggi ${ }^{2}$ \& Alessandro Gaetano ${ }^{1}$ \\ ${ }^{1}$ Management and Law Department, University of Rome Tor Vergata, Rome, Italy \\ ${ }^{2}$ Business Administration Department, University of Verona, Verona, Italy \\ Correspondence: Sara Moggi, Business Administration Department, University of Verona, Verona, Italy, Via \\ Cantarane 24, 37129, Italy. E-mail: sara.moggi@univr.it
}

Received: October 12, 2020

Accepted: November 8, 2020

Online Published: December 4, 2020

doi:10.5539/ijbm.v16n1p8

URL: https://doi.org/10.5539/ijbm.v16n1p8

\begin{abstract}
Directive 2014/95/EU was released with the aim of improving the transparency, comparability and harmonization of non-financial reporting among European undertakings. However, the Directive is vague regarding both non-financial disclosure contents and the transposition of its provisions into national European laws, making it somewhat ambiguous. This issue has been underlined by scholars, who have found the comparison of non-financial disclosures challenging and have not seen a considerable improvement in the level of transparency. This is also mirrored in the assurance process, which remains underexplored. The present exploratory study analyses non-financial disclosure assurance in the Italian financial services sector. Content analysis of the level and features of assurance of non-financial disclosures published in 2020 was conducted. The results show that the ambiguity of the Directive also has consequences for assurance outcomes, which remain limited and strictly adhere to provisions provided by national practitioner associations.
\end{abstract}

Keywords: non-financial disclosure, assurance, bank, content analysis, audit

\section{Introduction}

The European Union (EU) (2014) Directive 2014/95/EU was released with the aim of improving the level of transparency and comparability of non-financial disclosures (NFDs) of large undertakings operating in the EU. The aim of the Directive was supported by increasing claims of poor accountability in non-financial information (NFI) inside NFDs by a wide range of stakeholders, including shareholders, customers, environmentalists, and suppliers. The need for accountability has arisen partially from increasing stakeholder awareness of companies' economic, social and environmental impacts. Directive 2014/95/EU is the result of these stakeholders' claims, even though they were not directly involved in its development (Biondi, Dumay, \& Monciardini, 2020; La Torre, Sabelfeld, Blomkvist, \& Dumay, 2020). The implications of Directive 2014/95/EU in terms of trust are multiple as disclosure of social and environmental aspects can steer the process of company legitimation from its stakeholders. Companies disclosing NFI can demonstrate their performance to stakeholders, who may compare NFDs with those from other companies (Masiero, Arkhipova, Massaro, \& Bagnoli, 2019).

Although Directive 2014/95/EU requires Member States to conduct audits on NFDs, it does not specify how and to what extent auditing procedures should be carried out. Member States were obliged to gradually transpose the Directive's provisions into their national legal systems but were given a large margin for implementation. This has meant that the transposition has not supported the harmonization and comparability of NFDs nor reduced the well-known risk of greenwashing (Glover \& Touboulic, 2020; Siano, Vollero, Conte, \& Amabile, 2017). Social accounting scholars have underlined the importance of assurance as a valuable tool to improve the credibility and legitimacy of NFDs for stakeholders (Belal \& Owen, 2015; Chen, Patten, \& Roberts, 2008; Deegan, 2002).

Despite the large body of literature on assurance of sustainability reports (Nishitani, Haider, \& Kokubu, 2020; Velte, 2017; Perego \& Kolk, 2012; Simnett, Vanstraelen, \& Chua, 2009), few studies have explored the NFD assurance process, calling for further research on this topic (Lajmi \& Paché, 2020; Martinez-Ferrero \& Garcia-Sanchez, 2017; Venturelli, Pizzi, Caputo, \& Principale, 2020). Seguí-Mas, Polo-Garrido and Bollas-Araya (2018) have also underlined the lack of research on NFD assurance in the financial services sector. 
Given the lack of research on NFD assurance, the present paper aims to increase the understanding of its actual practices and potential criticisms. To meet this aim, the following research questions were formulated:

\section{How and to what extent are NFD assurances provided?}

\section{What are the main tests conducted for providing assurance?}

To answer the research questions, the Italian financial services sector was explored. The focus was limited to the Italian context to enhance comparisons of collected data and explore national institutional influences, including normative aspects (e.g. from Assirevi's research reports) and legal provisions (e.g. Legislative Decree No. 254/2016). Although the results are not generalisable, the insights may reflect general issues related to NFD and its assurance (Parker \& Northcott, 2016).

The paper's contribution is twofold. First, critically analysing the transposition of NFD assurance this study will provide practical insights for the legitimacy of auditors that face the challenge of assuring NFI. Second, the paper contributes to the scant literature on NFD assurance and its implementation at the national level.

The paper is structured as follows: Section 2 provides a summary of the main literature on NFD assurance, including research papers and laws released by the Italian government and practitioner associations. Section 3 presents the data collection and content analysis procedures. Section 4 provides the main results of the NFD audit analysis. Section 5 discusses the findings and concludes the paper, reflecting on the criticisms of assurance provisions in terms of legal requirements and the explorative results from the present paper.

\section{Literature Review}

\subsection{Main Implications of Non-Financial Disclosure}

Social accounting scholars agree that sustainability reporting, in its numerous forms, is a potential tool for obtaining and maintaining legitimacy in the eyes of both internal and external stakeholders (Deegan, Rankin, \& Tobin, 2002). Legitimacy is a resource upon which organisations depend for survival but is also a tool that may be manipulated by organisations (Deegan, 2002; Woodward, Edwards, \& Birkin, 2001). Consequently, the management of sustainability reports and their publication is crucial in enhancing trust from a wide range of stakeholders (Masiero et al., 2019; Mio \& Venturelli, 2013).

Banks are expected to play a pivotal role in corporate sustainability through, for example, the inclusion of environmental, social and governance criteria in their investment and lending practices (Buallay, Fadel, Alajmi, \& Saudagaran, 2020). Studies in the financial services sector exploring factors influencing financial performance have highlighted the positive effects of social responsibility disclosure (Cornett, Erhemjamts, \& Tehranian, 2016; Platonova, Asutay, Dixon, \& Mohammad, 2018; Simpson \& Kohers, 2002), corporate governance (Aebi, Sabato, \& Schmid, 2012) and environmental friendliness (Jo, Kim, \& Park, 2015; Nizam, Ng, Dewandaru, Nagayev, \& Nkoba, 2019). Nevertheless, despite the numerous social accounting studies in financial services, research on NFD is still lacking.

Directive 2014/95/EU obliged EU Member States to undertake a complex transposition process between 2014 and 2016, which involved rearranging the Directive requirements into their own legislative systems (La Torre, Sabelfeld, Blomkvist, Tarquinio, \& Dumay, 2018). This has resulted in the development of laws and regulations with various features and provisions (Aureli, Magnaghi, \& Salvatori, 2018; Luque-Vílchez \& Larrinaga, 2016; Mio, Fasan, Marcon, \& Panfilo, 2020). Preliminary studies on large European companies show that there were varying levels of disclosure during the transposition process (Alliance for Corporate Transparency, 2019; Global Reporting Initiative [GRI] \& Corporate Social Responsibility Europe, 2017). Studies have primarily focused on how the Directive provisions and related national laws have influenced the level and quality of NFD. In the Italian context, Venturelli, Caputo, Cosma, Leopizzi and Pizzi (2017) evaluated the NFDs of 223 large companies in Italy by scoring them on specific items related to the requirements of the national law on NFD. Moreover, Venturelli, Caputo, Leopizzi and Pizzi (2018) conducted a cross-country analysis of British and Italian listed companies using non-financial scores, showing that the UK companies were more compliant with the Directive than were Italian companies. According to the authors, 'This better level of quality for the UK is probably due to the fact that the UK had adopted regulation[s] about NFI before Italy' (Venturelli et al., 2018, p. 419).

With respect to the EU guidelines on NFI (2017/C215/01) released in 2017, Manes-Rossi, Tiron-Tudor, Nicolò, and Zanellato (2018) analysed the 50 largest companies in Europe, finding a high level of compliance with the guidelines. Adopting a legitimacy theory perspective in the European context, the authors found that, following the imposition of the Directive, environmentally sensitive industries provided a more comprehensive disclosure of their social and environmental impact to 'reduce the potential concern by the communities in which they are 
rooted and to gain respect on the market and thus legitimize their actions' (Manes-Rossi et al., 2018, p. 16). Previous studies have also found an increasing use of integrated reporting, in which financial information and NFI are consolidated into one document, providing a more comprehensive picture of the firm and preventing double reporting (Monciardini, 2016; Nicolò, Zanellato, \& Tiron-Tudor, 2020).

Another significant criticism of the Directive is the challenge in defining the material aspects of NFD. This is also due to the lack in the Directive of a clear reference to a specific standard (Biondi \& Bracci, 2018). According to the GRI's (2013b) sustainability reporting guidelines, materiality reflects an organisation's significant economic, social and environmental impacts that may influence the assessments and decisions of stakeholders. The Italian professional association Assirevi (2019) - that supports the adoption of auditing standards considering the evolution of legislation - has underlined that the material aspects described in Legislative Decree No. 254/2016 (art. 3) include the business model, corporate policy, key performance indicators of NFI, company risks and use of water and energy resources.

\subsection{Non-Financial Disclosure Assurances}

While the majority of studies have focused on the main implications of the Directive and national laws on the disclosure of NFI, little attention has been paid to NFD assurance (Bozzolan \& Miihkinen, 2019; Venturelli et al., 2020). Assurance procedures for reports on sustainability and social responsibility play a pivotal role in supporting the credibility of NFDs (Farooq \& de Villiers, 2017). Thus, assurances can provide a guarantee on the content of sustainability reports, assure the quality of disclosure and reduce the risk of greenwashing (Glover \& Touboulic, 2020; Seguí-Mas et al., 2018; Siano et al., 2017). As noted in previous studies, management decisions to procure a third party necessary to assure a sustainability report are important to increase a company's legitimacy (Bagnoli \& Watts, 2017; Fernandez-Feijoo, Romero, \& Ruiz, 2015). Directive 2014/95/EU on NFD assurance explains this as follows:

Statutory auditors and audit firms should only check that the non-financial statement or the separate report has been provided. In addition, it should be possible for Member States to require that the information included in the non-financial statement or in the separate report be verified by an independent assurance services provider. (EU, 2014, p. 3).

Given that assurance is considered a process for improving the credibility of reporting and trust in the company's actions (Hassan, Elamer, Fletcher, \& Sobhan, 2020), this goal may be difficult to achieve if assurance rules are general and the content of the NFD audit is not defined. The Directive leaves Member States to decide on the particulars of NFD assurance. Article 10 of Legislative Decree No. 254/2016 states the following:

The person in charge of carrying out the legal audit of the financial statements verifies that the non-financial statement has been prepared by the directors. The same person, or another person authorized to carry out the legal audit, expresses, with a specific separate report [and] a certification regarding the consistency of the information provided in compliance with the law decree.

To guide the assurance process, the Italian professional association Assirevi has released a research report to provide support for auditors. Research Report No. 226 (Assirevi, 2019) focuses on NFD auditing and discusses the objectives of assurance engagements according to the International Standard on Assurance Engagements (ISAE) 3000 (Revised) (International Auditing and Assurance Standards Board [IAASB], 2013), which provides for two forms of assurance - either reasonable and limited — or a mix of both. The two approaches differ in their procedures-limited assurance is lower in extent and depth compared with reasonable assurance. Following reasonable assurance engagement, the written report should conclude with a statement similar to the following: 'In our opinion, the information has been provided, in all significant aspects, in compliance with the law'. Following the limited assurance engagement, the written report should conclude with a statement similar to the following: 'On the basis of the work carried out, no elements have come to our attention that lead us to believe that the information has not been prepared, in all significant aspects, in compliance with the law' (IAASB, 2013). Assirevi (2019) also offers assurance report prototypes for supporting auditors in conducting assurance. According to previous social accounting studies, this research report may be considered the result of normativity arising from the law and usual audit practices (Bebbington, Kirk, \& Larrinaga, 2012).

\section{Method}

\subsection{Sample Preparation and Data Collection}

Sample selection was based on identification of banks and insurance firms from all Italian companies providing NFD and listed on the Commissione Nazionale per le Società e la Borsa (CONSOB) website in 2020. CONSOB is the public authority responsible for regulating Italian financial markets and lists on its website all companies 
that have published NFDs in accordance with Legislative Decree No. 254/2016. Forty-six companies were identified and their NFDs downloaded from their official websites. Updated NFDs were not available for eight companies, which were excluded from the analysis. The remaining 38 companies had published NFDs for the 2019 fiscal year in 2020. These NFDs represented the final sample for analysis, which included 19 listed companies, six of which were insurance companies, and 32 banks. It was decided to focus on the financial services sector to enhance the comparability of data and respond to literature underlining that social accounting practices in this sector remain under investigated in comparison with others (Korzeb \& Samaniego-Medina, 2019; Krasodomska, 2015; Rebai, Azaiez, \& Saidane, 2016; Seguí-Mas et al., 2018).

\subsection{Content Analysis Protocol}

Following identification of the sample, content analysis of the 38 downloaded NFDs was conducted to identify the main issues related to assurance. Content analysis is a research method useful for investigating problems in which reported information is the base of inference (Holsti, 1969; Unerman \& Bennett, 2004). It has been largely employed in social accounting studies to improve the understanding of sustainability reports (Beck, Campbell, \& Shrives, 2010; Gray, Javad, Power, \& Sinclair, 2001) and has recently been applied to exploring NFD (Carini, Rocca, Veneziani, \& Teodori, 2018; Doni, Bianchi Martini, Corvino, \& Mazzoni, 2019). Content analysis technique permits to explore and infer the contents of reports with consideration of the meanings of words and their lexical context (Holsti, 1969; Moggi, 2019). The analysis was carried out by two independent researchers. Following Krippendorff's (2013) protocol for enhancing the reliability of content analysis, Krippendorff's $\alpha$ was calculated as a measure of the agreement coefficient between multiple coders. The average value for this coefficient was 0.97 , which is significantly higher than the acceptable level $(0.80)$ of intercoder reliability (Hackston \& Milne, 1996; Milne \& Adler, 1999). In cases of disagreement, a third researcher was employed as an external auditor (Creswell, 2003). All 38 NFDs were analysed using content analysis, which was based on two core dimensions, encompassing 24 aspects overall (see Table 1). The first dimension focused on the main features of the NFDs, such as the standards mentioned in the materiality provisions. The second dimension focused on NFD assurance, including coding of its features and the assurance tests used (e.g. test typologies, level of assurance). The stability of content analysis results was enhanced using the test-retest procedure (Krippendorff, 2018). The following section presents the content analysis results with consideration of the abovementioned dimensions.

Table 1. Framework used for the content analysis

\begin{tabular}{ll}
\hline Dimensions & Aspects \\
\hline & Where NFD is located in the reporting system \\
Main features of NFD & Nundard applied \\
& Materiality analysis \\
& Function/staff in charge of the NFD reporting \\
& Presence of the assurance report \\
\hline & Number of assurance report pages \\
& Auditor of NFD \\
& Auditor of financial statement \\
& Level of the assurance \\
& Test typologies \\
Boundaries of NFD \\
Link between NFD and financial statement \\
Presence of qualitative and qualitative information \\
Indicators \\
Interviews with personnel \\
Site visits \\
Assurance result \\
\hline
\end{tabular}




\section{Results}

\subsection{General Aspects of Non-Financial Disclosure}

According to the Italian Regulation, NFD may be included in a company's management report or presented as a separate document. In our sample, $82 \%$ of companies presented their NFI as separate documents, which assumed different forms (e.g. NFD report, sustainability report, or integrated report). The structure of these reports varied greatly and did not follow a common reporting framework. NFDs included in management reports were similar in structure and followed the requirements of Legislative Decree No. 254/2016. Although this decree does not refer to a specific international standard for NFDs, all documents referred to the GRI. This commonality is supported by the Research Report No. 232 released by Assirevi (2020). While Assirevi does not explicitly recommend the adoption of the GRI standard for NFD, it does recommend it for corporate sustainability reports and when corporate sustainability reports and NFDs overlap. In addition to GRI's main standard (GRI, 2013b), other standards mentioned included the GRI's (2013a) Financial Services Sector Disclosures and the International Integrated Reporting Council's (2013) International $\langle I R>$ Framework for integrated reporting. Because NFD reports are often unstructured, to comply with the Legislative Decree No. 254/2016, they indicated where the various required contents, including GRI indices, were located in the document (e.g. section or page). The length of reports ranged from 10 to 224 pages, with an average of 113 pages. Given that the NFDs were facsimiles of the auditor report presented in Assirevi's (2019) Research Report No. 226, it was surprising to find that in all 38 NFDs, materiality was defined using different boundaries of the report.

\subsection{Assurance Features and Extent}

Each analysed NFD had an attached auditor report with an average length of 3.18 pages. The main assurance provider was Deloitte \& Touche, followed by EY Assurance, KPMG and PricewaterhouseCoopers (see Table 2). These data are in accordance with general trends in the audit service market (CONSOB, 2020).

Table 2. Assurance providers for non-financial disclosures

\begin{tabular}{ll}
\hline Organisation & $\%$ of assured non-financial disclosures $(N)$ \\
\hline Deloitte \& Touche & $28.95 \%(11)$ \\
EY Assurance & $21.05 \%(8)$ \\
KPMG & $21.05 \%(8)$ \\
PricewaterhouseCoopers & $21.05 \%(8)$ \\
BDO Italia & $5.26 \%(2)$ \\
Mazars Italia & $2.64 \%(1)$ \\
\hline
\end{tabular}

In the majority of cases, the assurance providers for the NFDs were the same firms that audited the company's financial statements. In only two cases, two separate firms (BDO Italia and KPMG) were used for financial statements and NFD assurances. According to the type of assignment given by the audited company, auditors' conclusions were expressed as a limited assurance of the NFD as a whole, a reasonable assurance or a mixed assurance (e.g. limited assurance of the NFD as a whole and reasonable assurance for some information contained in the report) (IAASB, 2013). In all analysed cases, the provided level of assurance was limited and referred to the ISAE 3000 (Revised) (IAASB, 2013), which is also supposed by Research Report No. 226 (Assirevi, 2019).

With respect to the tests carried out by auditors on NFDs, Figure 1 shows that general evaluations were conducted by all 38 analysed companies. In particular, document review, generation and assessment of qualitative data and compliance with art. 3 of Legislative Decree No. 254/2016 were presented in all auditor reports. Scope of consolidation was required only for listed companies, with a coverage of $89.47 \%$. A more complex process was comparing NFD data with financial statements $(84.21 \%)$ because NFD data are often reclassified or altered. As sustainability reports, NFDs are rich in qualitive information, and interviews are a diffused practice in assurance. According to our analysis, all analysed companies conducted interviews with personnel to assess information such as employees' work quality, health plans, security and training activities. For listed companies, interviews were often also conducted with personnel in other branches $(50 \%)$ and were typically coupled with onsite inspections or visits. 


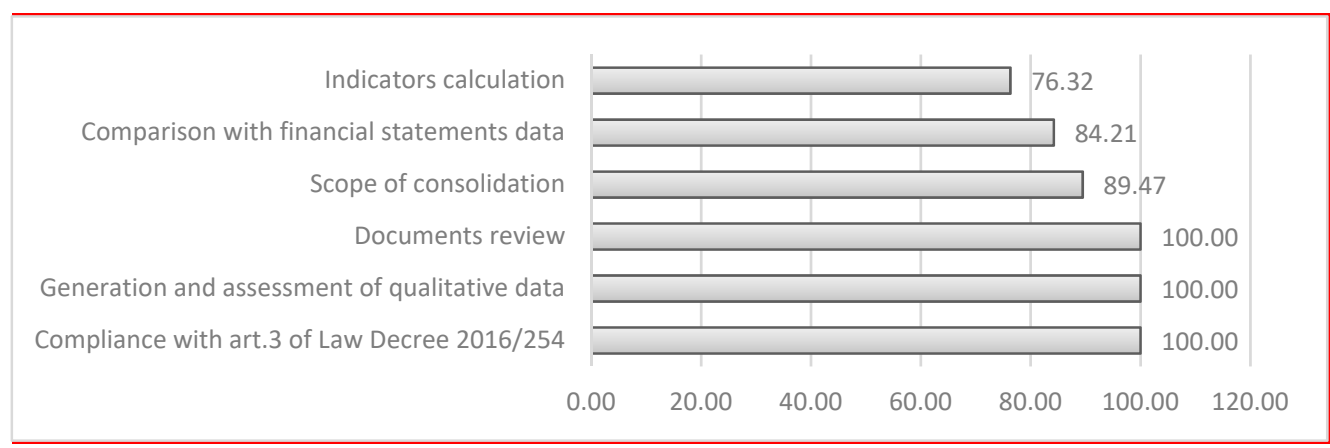

Figure 1. Tests conducted for non-financial disclosure assurance

\section{Discussion and Conclusions}

Directive 2014/95/EU has entered into force in all EU Member States and was released with the aim of enhancing the comparability and coherence of the NFDs of undertakings in the European context. Despite this, early studies on NFD have revealed only a slight improvement in transparency and little comparability between reports. This lack of improvement is mainly attributable to the ambiguity of the Directive, which once transposed to national laws, left EU countries with an ample margin for adapting the NFD requirements to the local context. The ambiguous boundaries regarding materiality are a consequence of the Directive's vagueness. The lack of clear direction for NFD has also steered the NFD assurance process. While numerous studies have supported the abovementioned concerns about NFDs, few have critically analysed the assurance aspects (Bozzolan \& Miihkinen, 2019; Venturelli et al., 2020).

Being relatively new, NFD assurance presents a challenge for auditors. The legal provisions arising from the Directive and its transpositions mandate only the presence of assurance along with limited criteria described in national laws. As noted by previous studies, audits on NFD are important for gaining trust and legitimacy from stakeholders; however, when they are limited or vague, they may paradoxically be viewed as greenwashing (Glover \& Touboulic, 2020; Siano, Vollero, Conte, \& Amabile, 2017).

In analysing how and to what extent NFD assurance is provided, the present study considered NFD assurance practices in the Italian financial services sector. The results show that the main features and assurance of NFDs in the financial services sector overall are consistent. The GRI is the main standard applied in identifying indices for NFDs. NFD assurance is generally carried out by one of the Big 4 accounting firms in similar formats based on recommendations by Assirevi. Thus, the lack of legislative provisions clearly defining the content of NFD both at the EU and national levels is driving assurance procedures that cannot be framed into a specific process or in accordance with established controls and procedures. In accordance with legislation, auditors can simply certify the presence (or absence) of NFD and conduct procedures to ensure limited assurance (see Figure 2).

General law provisions

Audit provisions

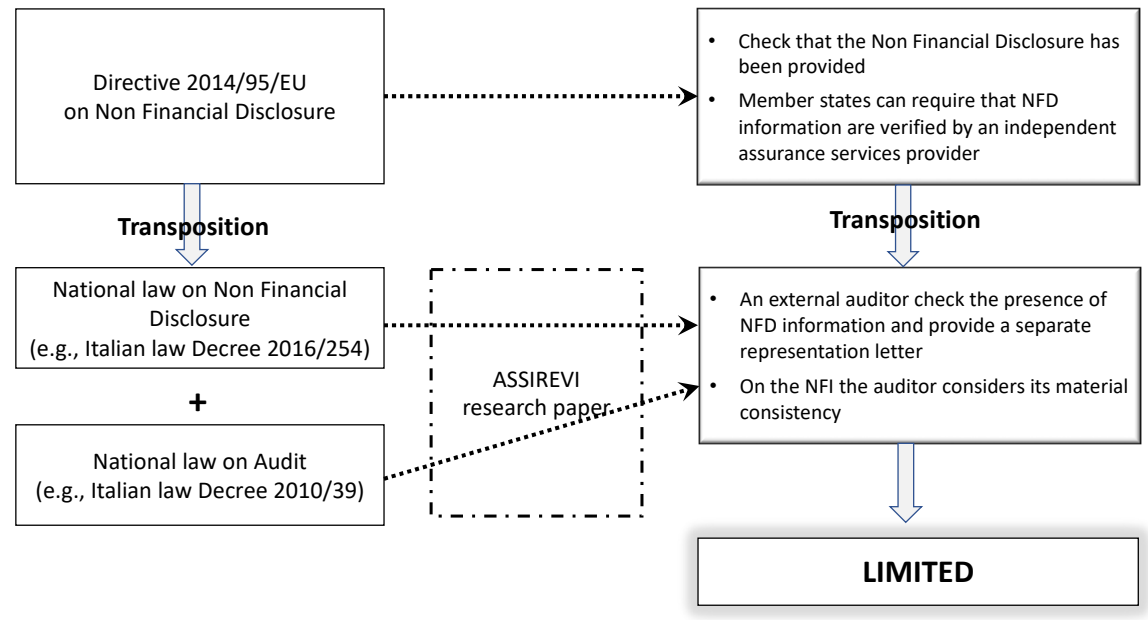

Figure 2. Legislation and Normative Pressures for Non-Financial Disclosure Assurance (Italian Context) 
The need for specific provisions is satisfied by professional associations. Assirevi has supported the task of auditors by releasing Research Reports 226 and 232, which have strongly influenced Italian NFD content (e.g. GRI indices) and assurance. As a trustworthy professional organisation at the national level, Assirevi influences the practices of both disclosing companies and auditors. In this situation, an approach from below should steer future legislative provisions because it remains doubtful that assurance statements will improve stakeholder trust in companies if they are simply the result of normative pressures (Bebbington et al., 2012).

The main limitation of the present study, being explorative in nature, is the narrow boundaries of the sample, which focused only on the Italian financial services sector. In light of this issue, future studies should consider a larger sample encompassing various sectors and national contexts, bearing in mind that different institutional pressures could also steer NFDs and their assurance procedures.

\section{Acknowledgments}

The authors would like to thank Francesca Sartor for her valuable support in data collection.

\section{References}

Aebi, V., Sabato, G., \& Schmid, M. (2012). Risk management, corporate governance, and bank performance in the financial crisis. Journal of Banking \& Finance, 36, 3213-3226. https://doi.org/10.1016/j.jbankfin.2011.10.020

Alliance for Corporate Transparency. (2019). The Alliance for Corporate Transparency research report 2019: An analysis of the sustainability reports of 1000 companies pursuant to the EU Non-Financial Reporting Directive. Brussels, Belgium: Author. Retrieved from http://allianceforcorporatetransparency.org/assets/2019_Research_Report\%20_Alliance_for_Corporate_Tra nsparency-7d9802a0c18c9f13017d686481bd2d6c6886fea6d9e9c7a5c3cfafea8a48b1c7.pdf

Assirevi. (2019). La relazione della società di revisione indipendente sulla dichiarazione non finanziaria ai sensi del d.lgs. 254/2016 e dell'art. 5 del regolamento Consob adottato con delibera n. 20267 del gennaio 2018 [The report of the independent auditing firm on the non-financial statement pursuant to Legislative Decree 254/2016 and art. 5 of the Consob Regulation adopted with Resolution no. 20267 of January 2018] (Research Report No. 226). Milan, Italy: Author. Retrieved from http://www.assirevi.com/documenti-assirevi/documenti-di-ricerca/documenti-in-vigore/

Assirevi. (2020). Relazione della società di revisione indipendente sul bilancio di sostenibilità-GRI standards [Independent auditor's report on the sustainability report-GRI standards] (Research Report No. 232). Milan, Italy: Author. Retrieved from http://www.assirevi.com/documenti-assirevi/documenti-di-ricerca/documenti-in-vigore/

Aureli, S., Magnaghi, E., \& Salvatori, F. (2018). The transposition of the non-financial reporting directive in the UK, France and Italy. Symphonya. Emerging Issues in Management, (1), 48-67. https://doi.org/10.4468/2018.1.04aureli.magnaghi.salvatori

Bagnoli, M., \& Watts, S. G. (2017). Voluntary assurance of voluntary CSR disclosure. Journal of Economics \& Management Strategy, 26, 205-230. https://doi.org/10.1111/jems.12171

Bebbington, J., Kirk, E. A., \& Larrinaga, C. (2012). The production of normativity: A comparison of reporting regimes in Spain and the UK. Accounting, Organizations and Society, 2, 78-94. https://doi.org/10.1016/j.aos.2012.01.001

Beck, A. C., Campbell, D., \& Shrives, P. J. (2010). Content analysis in environmental reporting research: Enrichment and rehearsal of the method in a British-German context. The British Accounting Review, 42, 207-222. https://doi.org/10.1016/j.bar.2010.05.002

Belal, A., \& Owen, D. L. (2015). The rise and fall of stand-alone social reporting in a multinational subsidiary in Bangladesh: A case study. Accounting, Auditing \& Accountability Journal, 28, 1160-1192. https://doi.org/10.1108/aaaj-08-2013-1443

Biondi, L., \& Bracci, E. (2018). Sustainability, popular and integrated reporting in the public sector: A fad and fashion perspective. Sustainability, 10. https://doi.org/10.3390/su10093112

Biondi, L., Dumay, J., \& Monciardini, D. (2020). Using the International Integrated Reporting Framework to comply with EU Directive 2014/95/EU: Can we afford another reporting façade? Meditari Accountancy Research, 28, 889-914. https://doi.org/10.1108/medar-01-2020-0695

Bozzolan, S., \& Miihkinen, A. (2019). The quality of mandatory non-financial (risk) disclosures: the 
moderating role of audit firm and partner characteristics. The International Journal of Accounting. Advance online publication. https://doi.org/10.2139/ssrn.3342703

Buallay, A., Fadel, S. M., Alajmi, J., \& Saudagaran, S. (2020). Sustainability reporting and bank performance after financial crisis. Competitiveness Review: An International Business Journal. Advance online publication. https://doi.org/10.1108/cr-04-2019-0040

Carini, C., Rocca, L., Veneziani, M., \& Teodori, C. (2018). Ex-ante impact assessment of sustainability information-The directive 2014/95. Sustainability, 10, 560-583. https://doi.org/10.3390/su10020560

Chen, J. C., Patten, D. M., \& Roberts, R. W. (2008). Corporate charitable contributions: A corporate social performance or legitimacy strategy? Journal of Business Ethics, 82, 131-144. https://doi.org/10.1007/s10551-007-9567-1

Commissione Nazionale per le Società e la Borsa. (2020). Relazione per l'anno 2019 [Report for the year 2019]. Rome, Italy: Author. Retrieved from www.consob.it/documents/46180/46181/rel2019.pdf/12ba0788-ec9b-4c53-80fd-e91c6a5de98a

Cornett, M. M., Erhemjamts, O., \& Tehranian, H. (2016). Greed or good deeds: An examination of the relation between corporate social responsibility and the financial performance of US commercial banks around the financial crisis. Journal of Banking \& Finance, 70, 137-159. https://doi.org/10.1016/j.jbankfin.2016.04.024

Creswell, J. W. (2003). Research design: Qualitative, quantitative, and mixed methods approaches (2nd ed.). London, United Kingdom: Sage.

Deegan, C. M. (2002). Introduction: The legitimising effect of social and environmental disclosures-a theoretical foundation. Accounting, Auditing \& Accountability Journal, 15, 282-311. https://doi.org/10.1108/09513570210435852

Deegan, C. M., Rankin, M., \& Tobin, J. (2002). An examination of the corporate social and environmental disclosures of BHP from 1983-1997: A test of legitimacy theory. Accounting, Auditing \& Accountability Journal, 15, 312-343. https://doi.org/10.1108/09513570210435861

Doni, F., Bianchi Martini, S., Corvino A. (2019). Exploring integrated reporting in the banking industry: the multiple capitals approach. Journal of Intellectual Capital, 20(1). https://doi.org/10.1108/JIC-11-2017-0146

European Union. (2014). Directive 2014/95/EU of the European Parliament and of the Council of 22 October 2014 amending Directive 2013/34/EU as regards disclosure of non-financial and diversity information by certain large undertakings and groups. Brussels, Belgium: Author. Retrieved from https://eur-lex.europa.eu/legal-content/EN/TXT/PDF/?uri=CELEX:32014L0095

Farooq, M. B., \& de Villiers, C. (2017). The market for sustainability assurance services: A comprehensive review of the literature and future avenues for research. Pacific Accounting Review, 29, 79-106. https://doi.org/10.1108/par-10-2016-0093

Fernandez-Feijoo, B., Romero, S., \& Ruiz, S. (2015). Multilevel approach to sustainability report assurance decisions. Australian Accounting Review, 25, 346-358. https://doi.org/10.1111/auar.12104

Global Reporting Initiative. (2013a). G4 Financial services sector disclosures. Amsterdam, The Netherlands: Author.

Global Reporting Initiative. (2013b). G4 Sustainability reporting guidelines: Reporting principles and standard disclosures. Amsterdam, The Netherlands: Author. Retrieved from https://www.globalreporting.org

Global Reporting Initiative, \& Corporate Social Responsibility Europe [in collaboration with Accountancy Europe]. (2017). Member State implementation of Directive 2014/95/EU: A comprehensive overview of how Member States are implementing the EU Directive on non-financial and diversity information. Brussels, Belgium: Author. Retrieved from https://www.accountancyeurope.eu/wp-content/uploads/1711-NFRpublication-GRI-CSR-Europe.pdf

Glover, J., \& Touboulic, A. (2020). Tales from the countryside: Unpacking "passing the environmental buck" as hypocritical practice in the food supply chain. Journal of Business Research, 121, 33-46. https://doi.org/10.1016/j.jbusres.2020.06.066

Gray, R., Javad, M., Power, D. M., \& Sinclair, C. D. (2001). Social and environmental disclosure and corporate characteristics: A research note and extension. Journal of Business Finance \& Accounting, 28, 327-356. https://doi.org/10.1111/1468-5957.00376 
Hackston, D., \& Milne, M. J. (1996). Some determinants of social and environmental disclosures in New Zealand companies. Accounting, Auditing \& Accountability Journal, 9, 77-108. https://doi.org/10.1108/09513579610109987

Hassan, A., Elamer, A. A., Fletcher, M., \& Sobhan, N. (2020). Voluntary assurance of sustainability reporting: Evidence from an emerging economy. Accounting Research Journal, 33, 391-410. https://doi.org/10.1108/arj-10-2018-0169

Holsti, O. R. (1969). Content analysis for the social sciences and humanities. Reading, MA: Addison-Wesley.

International Auditing and Assurance Standards Board. (2013). International Standard on Assurance Engagements (ISAE) 3000 (revised): Assurance engagements other than audits or reviews of historical financial information. New York, NY: Author. Retrieved from https://www.ifac.org/system/files/publications/files/ISAE 3000 Revised - for IAASB.pdf

International Integrated Reporting Council. (2013). The International $<I R>$ Framework. Retrieved from https://integratedreporting.org/wp-content/uploads/2013/12/13-12-08-THE-INTERNATIONAL-IR-FRAM EWORK-2-1.pdf

Jo, H., Kim, H., \& Park, K. (2015). Corporate environmental responsibility and firm performance in the financial services sector. Journal of Business Ethics, 131, 257-284. https://doi.org/10.1007/s10551-014-2276-7

Korzeb, Z., \& Samaniego-Medina, R. (2019). Sustainability performance: A comparative analysis in the Polish banking sector. Sustainability, 11, 653. https://doi.org/10.3390/su11030653

Krasodomska, J. (2015). CSR disclosures in the banking industry. Empirical evidence from Poland. Social Responsibility Journal, 11, 406-423. https://doi.org/10.1108/srj-02-2013-0019

Krippendorff, K. (2013). Content analysis: An introduction to its methodology (3rd. ed.). Los Angeles, CA: Sage.

Krippendorff, K. (2018). Content analysis: An introduction to its methodology (4th ed.). Los Angeles, CA: Sage.

Lajmi, A., \& Paché, G. (2020). Relevance of voluntary environmental and social reporting in the French context: Does CSR assurance matter? Environmental Economics, 11(1), 54-64. https://doi.org/10.21511/ee.11(1).2020.05

La Torre, M., Sabelfeld, S., Blomkvist, M., \& Dumay, J. (2020). Rebuilding trust: Sustainability and non-financial reporting and the European Union regulation. Meditari Accountancy Research, 28, 701-725. https://doi.org/10.1108/medar-06-2020-0914

La Torre, M., Sabelfeld, S., Blomkvist, M., Tarquinio, L., \& Dumay, J. (2018). Harmonising non-financial reporting regulation in Europe: Practical forces and projections for future research. Meditari Accountancy Research, 26, 598-621. https://doi.org/10.1108/medar-02-2018-0290

Italian Government, Legislative Decree No. 254/2016, Attuazione della direttiva 2014/95/UE del Parlamento europeo e del Consiglio del 22 ottobre 2014, recante modifica alla direttiva 2013/34/UE per quanto riguarda la comunicazione di informazioni di carattere non finanziario e di informazioni sulla diversità da parte di talune imprese e di taluni gruppi di grandi dimensioni [Implementation of Directive 2014/95 / EU of the European Parliament and of the Council of 22 October 2014, amending Directive 2013/34 / EU as regards disclosure of non-financial and diversity information by certain large undertakings and groups] 30 December 2019. https://www.gazzettaufficiale.it/atto/stampa/serie_generale/originario

Luque-Vílchez, M., \& Larrinaga, C. (2016). Reporting models do not translate well: Failing to regulate CSR reporting in Spain. Social and Environmental Accountability Journal, 36, 56-75. https://doi.org/10.1080/0969160x.2016.1149301

Manes-Rossi, F., Tiron-Tudor, A., Nicolò, G., \& Zanellato, G. (2018). Ensuring more sustainable reporting in Europe using non-financial disclosure-De facto and de jure evidence. Sustainability, 10(4), 1162. https://doi.org/10.3390/su10041162

Martinez-Ferrero, J., \& Garcia-Sanchez, I. M. (2017). Sustainability assurance and assurance providers: Corporate governance determinants in stakeholder-oriented countries. Journal of Management \& Organization, 23, 647-670. https://doi.org/10.1017/jmo.2016.65

Masiero, E., Arkhipova, D., Massaro, M., \& Bagnoli, C. (2019). Corporate accountability and stakeholder connectivity. A case study. Meditari Accountancy Research, 28, 803-821. https://doi.org/10.1108/medar-03-2019-0463 
Milne, M. J., \& Adler, R. W. (1999). Exploring the reliability of social and environmental disclosures content analysis. Accounting, Auditing \& Accountability Journal, 12, 237-256. https://doi.org/10.1108/09513579910270138

Mio, C., Fasan, M., Marcon, C., \& Panfilo, S. (2020). The predictive ability of legitimacy and agency theory after the implementation of the EU directive on non-financial information. Corporate Social Responsibility and Environmental Management. Advance online publication. https://doi.org/10.1002/csr.1968

Mio, C., \& Venturelli, A. (2013). Non-financial information about sustainable development and environmental policy in the annual reports of listed companies: Evidence from Italy and the UK. Corporate Social Responsibility and Environmental Management, 20, 340-358. https://doi.org/10.1002/csr.1296

Moggi, S. (2019). Social and environmental reports at universities: A Habermasian view on their evolution. Accounting Forum, 43, 283-326. https://doi.org/10.1080/01559982.2019.1579293

Monciardini, D. (2016). The 'coalition of the unlikely' driving the EU regulatory process of non-financial reporting. Social and Environmental Accountability Journal, 36, 76-89. https://doi.org/10.1080/0969160x.2016.1149302

Nicolò, G., Zanellato, G., \& Tiron-Tudor, A. (2020). Integrated reporting and European state-owned enterprises: A disclosure analysis pre and post 2014/95/EU. Sustainability, 12, 1908. https://doi.org/10.3390/su12051908

Nishitani, K., Haider, M. B., \& Kokubu, K. (2020). Are third-party assurances preferable to third-party comments for promoting financial accountability in environmental reporting? Journal of Cleaner Production, 248, 119199. https://doi.org/10.1016/j.jclepro.2019.119199

Nizam, E., Ng, A., Dewandaru, G., Nagayev, R., \& Nkoba, M. A. (2019). The impact of social and environmental sustainability on financial performance: A global analysis of the banking sector. Journal of Multinational Financial Management, 49, 35-53. https://doi.org/10.1016/j.mulfin.2019.01.002

Parker, L., \& Northcott, D. (2016). Qualitative generalising in accounting research: Concepts and strategies. Accounting, Auditing \& Accountability Journal, 29, 1100-1131. https://doi.org/10.1108/aaaj-04-2015-2026

Perego, P., \& Kolk, A. (2012). Multinationals' accountability on sustainability: The evolution of third-party assurance of sustainability reports. Journal of Business Ethics, 110, 173-190. https://doi.org/10.1007/s10551-012-1420-5

Platonova, E., Asutay, M., Dixon, R., \& Mohammad, S. (2018). The impact of corporate social responsibility disclosure on financial performance: Evidence from the GCC Islamic banking sector. Journal of Business Ethics, 151, 451-471. https://doi.org/10.1007/s10551-016-3229-0

Rebai, S., Azaiez, M. N., \& Saidane, D. (2016). A multi-attribute utility model for generating a sustainability index in the banking sector. Journal of Cleaner Production, 113, 835-849. https://doi.org/10.1016/j.jclepro.2015.10.129

Seguí-Mas, E., Polo-Garrido, F., \& Bollas-Araya, H. M. (2018). Sustainability assurance in socially-sensitive sectors: A worldwide analysis of the financial services industry. Sustainability, 10, 2777. https://doi.org/10.3390/su10082777

Siano, A., Vollero, A., Conte, F., \& Amabile, S. (2017). "More than words": Expanding the taxonomy of greenwashing after the Volkswagen scandal. Journal of Business Research, 71, 27-37. https://doi.org/10.1016/j.jbusres.2016.11.002

Simpson, W. G., \& Kohers, T. (2002). The link between corporate social and financial performance: Evidence from the banking industry. Journal of Business Ethics, 35, 97-109. https://doi.org/10.1023/A:1013082525900

Simnett, R., Vanstraelen, A., \& Chua, W. F. (2009). Assurance on sustainability reports: An international comparison. The accounting review, 84, 937-967. https://doi.org/10.2308/accr.2009.84.3.937

Unerman, J., \& Bennett, M. (2004). Increased stakeholder dialogue and the internet: Towards greater corporate accountability or reinforcing capitalist hegemony? Accounting, Organizations and Society, 29, 685-707. https://doi.org/10.1016/j.aos.2003.10.009

Velte, P. (2017). Empirical research on corporate social responsibility assurance (CSRA): A literature review. Journal of Business Economics, 87, 1017-1066. https://doi.org/10.1007/s11573-016-0844-2 
Venturelli, A., Caputo, F., Cosma, S., Leopizzi, R., \& Pizzi, S. (2017). Directive 2014/95/EU: Are Italian companies already compliant? Sustainability, 9, 1385. https://doi.org/10.3390/su9081385

Venturelli, A., Caputo, F., Leopizzi, R., \& Pizzi, S. (2018). The state of art of corporate social disclosure before the introduction of non-financial reporting directive: A cross country analysis. Social Responsibility Journal, 15, 409-423. https://doi.org/10.1108/srj-12-2017-0275

Venturelli, A., Pizzi, S., Caputo, F., \& Principale, S. (2020). The revision of nonfinancial reporting directive: A critical lens on the comparability principle. Business Strategy and the Environment. Advance online publication. https://doi.org/10.1002/bse.2598

Woodward, D., Edwards, P., \& Birkin, F. (2001). Some evidence on executives' views of corporate social responsibility. British Accounting Review, 33, 357-397. https://doi.org/10.1006/bare.2001.0165

\section{Copyrights}

Copyright for this article is retained by the author(s), with first publication rights granted to the journal.

This is an open-access article distributed under the terms and conditions of the Creative Commons Attribution license (http://creativecommons.org/licenses/by/4.0/). 